\title{
The Politics of Oil in the Kurdistan Region of Iraq
}

\author{
Paiman Ramazan AHMAD ${ }^{1}$
}

\begin{abstract}
This research is aimed at identifying the role of petroleum revenues in the Kurdistan Region for better economic efficiency and sovereignty of the Kurdistan Region in the future. This study identifies some root causes of deficiency of revenue usage generally, as well as specific causes in the Kurdistan Region. Further, the study looks at the various factors that affect oil production in the Kurdistan Region and compares it to the Federal Government. This study seeks to show how the Kurdistan Region generates the oil reserves regionally, despite the difficulties it encounters with the Federal Government due to the constitutional ambiguity. The research analysis concludes the importance of energy efficiency for the Kurdistan Region both economically and politically.
\end{abstract}

Keywords: Kurdistan Region, Federal Government (Iraq), oil production, international legacy, constitutional dispute

\section{Introduction to the Petro-Region of Kurdistan (2007)}

According to Nawshirwan Mustafa, leader of the Change Party in the Kurdistan Region, "Iraqi government never wanted the Kurdistan Region to be independent economically, because that will give the chance for the Kurdistan Regional Government to become independent”. [43] The rise of oil production in recent years, typically in 2007, has dramatically transformed the economy of the Kurdistan Region. Many international oil companies (IOCs) poured into the region to extract cheap oil and get high profit out of the business; Sardar stated that "at the beginning the oil companies that invested in Kurdistan were small and not effective, but now there are globally known companies and very competitive”. [1] Notably, the Kurdistan Region became an important economic agent in Iraq. Its presence in the economy grew with the oil control and regionalization of revenues. Although, it might be counted as the aim for the Kurdistan Regional Government (KRG) to expand the power of the local government on the economic base, but on the other hand, generating the oil revenues was extremely needed for the KRG to re-build the region. Additionally, the Federal Government's policy towards the region, urged the KRG to sow the oil in the region for better economic developments, the oil boom appeared to be a tremendous blessing for the Kurdistan Region. Hence, the KRG passes its own hydrocarbons law, "the Oil and Gas Law of the Kurdistan Region in 2007”. [45]

The Prime Minister, Nechirvan Barzani, highlighted that this move is a "Historic moment", which "together with Iraq, the Constitution, will be the foundation of our economic development”, [2] and will allow the Kurdistan Regional Government to "choose the best,

Ph.D. in Public Administration, University of Raparin, Lecturer in Law and Administration departments, Rafia-Sulaimania-Kurdistan Region-Iraq. Teaching in Tishk International University-Erbil- previously "Ishik University” at Faculty of Administrative Sciences \& Economics, Department of International Relations \& Diplomacy, Erbil- Kurdistan Region -Iraq; e-mails: paiman.ramazan@gmail.com and paiman@raparinuni.org 
most experienced, the most committed investors” for the Region. The most important thing about the Kurdistan Region is the fact that the oil fields are untapped; the only good thing Saddam Hussein did was: he was late in generating the oil resources in the Kurdistan Region. In this view, Kurdistan is the youngest region that exports oil, and its capacity is increasing rapidly. Conversely, Guy pointed out that "Iraq is the toughest environment we operate in", says the Chief Executive of a big Western oil company.” [3] While, the stability and security of the Kurdistan Region are the immensely important factors for attracting foreign direct investors.

\section{How Oil Economically Shaped KRG as a Petro-Region?}

The economic growth of the region is the evidence of the oil revenues effectively generated recently by the regional government. The priority in the constitution of the KRG is given to the Investment Law, [4] and this is to be considered as the key driver of the foreign investment initiatives in the KRG. Since 2006, the KRG has managed to think about Investment Law, [4] and as well as the establishment of a separate institution which deals with investment in the KRG. Thus, in 2006 "the Kurdistan Board of Investment (BOI) was established, the main objective of BOI was to create new opportunities, and this was done by the legacy of the KRG Investment Law Article 5 which states that "a project shall be exempt from all non-custom taxes and duties for 10 years, starting from the date of providing service by the project, or the date of actual production”, [4] this law was passed by the Kurdistan National Assembly and was ratified by Masoud Barzani, the President of the Kurdistan Regional Government. Apparently, this law is the most essential factor for the dramatic growth in the economy of the Kurdistan Region. Moreover, the tax incentives and benefits were both attractive for the foreign investors, together with enjoying the same equal rights like the local companies were helpful for attracting foreign investors towards the region for building a sustainable and efficient economic system. In addition to that, the BOI law is the main factor for privatization of the petroleum revenues in the KRG as a developing market; and this has boosted the KRG position as a sovereign region in Iraq. The petroleum policy efficiency is driven from the investment policy of the KRG, which is different from the Federal Government. As it is acknowledged by Luis Martinez "the Kurdistan Region has a weak economic policy except for its oil sector policy. The more its oil sector grows, the more the region develops. It is a good idea for the Kurdistan Region to give more profit to the oil companies". [5] The core deficiency is that the domestic products of the region cannot meet the demand. Besides, the KRG is entitled to deliver the service to the public, and the demand for service is also increasing. The actual symptoms of the "Dutch Disease" in the KRG economy are observable factors. The KRG Minister of Agriculture, Abdul Star, Majid announced that "the government focus will be on boosting domestic agricultural products to decrease exports from outside; according to him this is the future policy of the KRG in the agriculture sector.” [6] The agricultural production shrank to less than what it was producing before the oil production; the dramatic decline in the domestic production had a general negative effect on the region. Perhaps, the most visible consequence of the Kurdistan Region's reliance on oil is that it was the only thing to depend on for the time being to build the economic infrastructure of the region from scratch. In fact, this had 
a political reason behind, which was the Iraqi Regime, which had devastated the agriculture sector in the Kurdistan Region. Although, currently the agriculture sector is not sufficient, historically agriculture played a significant role in the national economy of Kurdistan.” The KRG contribution to Iraqi agriculture production share is $50 \%$ of the nation's wheat, $40 \%$ of its barley, $98 \%$ of its tobacco, $30 \%$ of its cotton and $50 \%$ of its fruit. This means the KRG is doing better than the Federal Government, regardless of having lots of concerns in the agriculture sector, based on the data of the Ministry of Agriculture Profile, Directorate General of Planning and Follow-Up, Directorate of Statistics, Kurdistan Region, 2007. Kurdistan Development Corporation, Industry Sectors: Agriculture. [46]

\section{Politics of the Kurdistan Oil Market}

The Iraqi constitution guarantees that the Kurdistan Region is a federal region under Article 117/1: "First: This Constitution, upon coming into force, shall recognize the region of Kurdistan, along with its existing authorities, as a federal region.” [7: Art. 117/1] The Iraqi Constitution, Article 117/1 within this debate, the Kurdistan Region has dramatically exercised its monopoly over the regional reserves after the collapse of the Baath Regime. It is estimated that the majority of the public is employed in the formal economy, government sector. In line with this, the KRG needs sustainable financial resources to constantly support the population of the Kurdistan Region. To a great extent the Kurdistan Region's oil wealth has had a positive consequence for its political system, which might be turned into what political scientist Terry Lynn Karl stated as a "Pacted Democracy" in which the political parties agree on sharing the wealth of the country according to their voting, but what was in the KRG was different since the two main parties had control over the oil until 2007; the Kurdistan Region in many ways resembled a two-party regime, though it was governed by an alternating multi-party system. [8] At the most overt level, the conflict between the KRG and the Federal Government is about who controls the reserves. Beyond that, the dispute is: from where and how the KRG is shipping the oil, since the KRG is not a member state of the Organization of the Petroleum Exporting Countries (OPEC) and the International Monetary Fund (IMF) formally and the Federal Government wants to export all Iraqi oil from the State Oil Marketing Organization (SOMO). Hence, "SOMO is deemed by the federal government to be the sole body invested with the authority to organise the sale and export of Iraqi oil.” [9] Broadly speaking, the oil dependent states suffer during the oil crisis, and particularly when the oil price tumbles down, since this economic phenomenon leads to a severe crisis for the KRG. Because the KRG uses the oil wealth and redistributes it for the benefit of the community in different terms and programs, and it has created a social economy for the region. Unsurprisingly, the KRG has absolute control of the oil companies, and almost all of the foreign companies. Although, the economic sovereignty of the KRG is still an oil export driven economy, but the KRG has planted the seeds of oil to grow and transform the region gradually. Perhaps the most important key elements that the KRG has sought to solve were first and foremost reforms and bringing new foreign oil companies to invest in Kurdistan.

Boosting the efficiency of oil production in terms of internationalization balanced the role of the KRG the same as the Iraqi Government for the foreign oil import countries. 
The process of the refinery of the KRG oil is not sophisticated; hence the companies can handle it properly, because many oil revenues had been newly explored; therefore, it needs new construction and drilling, the risk of drilling for crude oil in the KRG is also low. The disagreement with the Federal Government and the KRG is accompanied by the natural resource distribution and sharing the capital. Moreover, the power of the KRG as a region shifted the Iraqi oil policy of centralization to a more decentralized dimension. Which is contradicting the notion of nationalism, "the oil market power transferred to state owned enterprises in the late 1970s, oil companies have been largely overpowered by the tide of nationalization?” [10] More prominently, [11] stated that “on $26^{\text {th }}$ February 2007, the Iraqi Cabinet passed and recommended for parliamentary approval a new law governing the country's immense and largely untapped supplies of oil and natural gas”. The ultimate goal of this law was first to control energy reserves all over Iraq and in particular those in the Kurdistan Region, besides that, it was what the United Stated wanted after the Iraqi invasion, to promote the role of foreign private companies to have a say in Iraqi energy industry. Furthermore, there was a significant potential in terms of the Production Sharing Agreements (PSAs), the ownership system of oil in the Federal Government, which since the 2003 invasion has become the nightmare for Iraqi politicians, as Muttitt highlighted that "straight after the war, was guided less by firm principles than by an ideological presumption that the oil industry's future lay in the IOCs' hands." [12] They "could not accept that there might be a legitimate political position that opposed transferring control [to the IOCs].” In an interview with the Minister of Natural Resources of the KRG, Ashti Hawrami stressed "the importance of regional management of the oil sector in which the benefit goes to the KRG residents, Iraq and the future generation.” [13]

Crucially, Hawrami added that the federal constitution of 2005, has fundamental concepts of power sharing and revenue sharing, it decentralizes the management of new oil and gas reserves in the country to the regions and governorates, it calls for joint rights in the old fields, though the Federal Government denies these rights by the regions to practise. From an early stage, the KRG thought strategically of efficient management of oil reserves; however, that contradicts the federal interest in oil production mainly. In fact, sharing oil profit with the private international companies who invest in oil production in Kurdistan brought key development into the oil field since 2005. The Kurdish approach "was to move swiftly to develop an investor-friendly legal regime for petroleum exploration and development, based on a model production sharing contract and a framework Petroleum law.” [14] It can hardly be doubted that this formed part of a wider agenda by the authorities to lay down a long-term economic basis for an independent Kurdish state. In fact, this effort has attracted more than two dozen of the International Oil Companies (IOCs). [14] The strategy that the KRG follows is in contradiction with the Federal Government, as the Federal Government avoids any "PSAs" and prefers the Technical Service Contracts (TSCs), in which it avoids the influence of the international oil companies in oil production; this is yet the best practise for the Federal Government. Although, according to the International Energy Agency figures, "PSAs are only used in respect of about $12 \%$ of world oil reserves, in countries where oilfields are small (and often offshore), production costs are high, and exploration prospects are uncertain. None of these conditions applies to Iraq”. It can be said that the Kurdistan Regional Government petroleum industry is based on the PSAs, which is considered to be a radical change in the oil and gas field management compared 
to the Federal Government regulations and system of energy management. "Investors use their capitals but share the profit, and the KRG believes such agreements provide vital encouragement for companies to increase their production in the region.” [15] The KRG Ministry of Natural Resource is seeking oil efficiency for better growth in the energy sector, though Baghdad bargained to stop the KRG from exporting oil, but this was not successful. As many multinational oil companies, such as "ExxonMobil, Chevro Total, and Gazprom," accepted to enter into the market production based on production sharing agreements. [16] The root of the dispute with the Iraqi Federal Government is dated back to 2004 when "the KRG independently signed a contract with the Norwegian Oil Company (NOC)", [10] in reaction to what the KRG did, the Federal Government decided to warn all foreign companies to avoid signing contracts with the KRG, since the company's federal contracts would be terminated.

Further, the action of the Federal Government was threatening and it was waging sanctions against any foreign company investing or even buying oil from the KRG, "SOMO, on behalf of the Iraqi federal ministry of oil, is hereby warning all companies, individuals and bodies from buying the Iraqi crude oil cargo that is loaded on the vessel”, [17] International oil companies are increasingly drawn to the region, as contracts to re-develop old oil fields and explore for new ones in southern Iraq turn out to be less attractive than anticipated.” [18] However, for some well-known oil companies, it was not easy to defy Baghdad and move to Kurdistan including Shell, which has a strong presence in three major oil and gas fields in Iraq, Shell has come close to securing contracts with the region twice before, but pulled back so as not to antagonise the central government in Baghdad, which regards all deals signed by the Kurdistan Regional Government as illegal. [19] Importantly, Shell has no interest to lose its interest in the federal contracts, but started to explore interest in Iraq as one entirety and wants to engage with the KRG oil market, too. The central government claims the illegality of oil export from the Kurdistan Region. But according to the Iraqi Constitution, Kurdistan is a Federal Autonomous Region and it has its own constitution, and the Petroleum law is well addressed by the regional constitution and it is in line with the federal constitution. Hence, it gives the right to generate and export oil. The ambiguous Iraqi Constitution, Article 109/1 highlights: "the federal government with the regions and governments shall undertake the management of oil and gas extracted from current fields provided that it distributes oil and gas revenues in a fair manner in proportion to the population distribution in all parts of the country with a set allotment for a set time for the damaged regions that were unjustly deprived by the former regime and the regions that were damaged later, as well in a way that assures balanced development in different areas of the country, and this will be regulated by law.” [7: Art. 109 para. 1]

Adding to this, the second part of Article 109 explains that "the central government with regional governments should work to formulate necessary policies and strategies for developing the oil and gas fields for achieving highest benefits for the Iraqi people.” [7: Art. 109 para. 2] According to the first part of Article 109 that states "current" which does not mean the future oil fields, but the current explored revenues before the 2005 constitution, not to mention that the Iraqi government never shows willingness in returning the capital that the Kurdistan Region deserves. And this made the KRG hesitate in returning the profit share to the central government. Since there is no trust and Baghdad has not shown willingness in providing the Kurdistan Region with the needs that the region needs. Despite the fact 
that Baghdad has always triggered the problem in the Kurdistan Region Oil development, and the successful economical experiences of Kurdistan were never welcomed by Baghdad, instead Baghdad always accused the Kurdistan Region over its independent oil production. This mistrust has historical and logical roots for the Kurdistan Region. Even though, Article 108 mentioned that "oil and gas are the property of the nation (people) of all the Regions and Governorates.” [7: Art. 108] On the ground, the government of Iraq is the owner of the oil wealth and the people of Iraq have never enjoyed the energy wealth. On the other hand, it is obvious that the Iraqi Constitution has no implication of "future revenues", it just mentions the oil resources without indicating them, as Article 111 says: "All powers not stipulated in the exclusive authorities of the federal government shall be the powers of the regions and governorates that are not organized in a region. The priority goes to the regional law in case of conflict between other powers shared between the federal government and regional governments.” [7: Art. 111]

According to Article 111, the power of the Kurdistan Region is to be taken into consideration legally and seriously. While the first paragraph of Article 117 states that "the regional powers shall have the right to exercise executive, legislative, and judicial powers in accordance with this Constitution, except for those authorities stipulated in the exclusive authorities of the federal government.” [7: Art. 117 para. 1] This completes what is missing in Article 111. In fact, a bilateral agreement between Erbil and Baghdad looks impossible; the Iraqi government has always practiced abusing its power over the KRG budget. Precisely, as alleged by the Kurdistan President's Chief of Staff, Fuad Hussien "Baghdad rejects mentioning the KRG as an oil producer in the official constitution, since Iraqi exports 3.4 million barrels of oil daily, and out of that almost 400,000 barrels (bbl) of it is exported by Kurdistan Region.” [44] This constitutionally jeopardizes the KRG to be an independent region as mentioned by the Iraqi Constitution. Additionally, Baghdad's latest ace was to nearly cut the Kurds out of the federal budget. The \$119 million budget for 2013 was passed on 7 March. The Kurds only got \$646 million of the \$3.5 billion they requested. [20] As a result, the KRG passed its regional Financial Rights Law on 23 April 2013: "Law of identifying and obtaining financial dues to the Kurdistan Region - Iraq from federal revenue. (The 'Financial Rights Law'.) The Financial Rights Law allows the KRG to independently export crude oil produced in the Kurdistan Region if the Federal Government fails to pay the KRG its share of revenues (including oil revenues), budget items, other national allocations and reparations.” [21]

In spite of all this, in January 2014 "the federal government practised suspending the KRG budget for almost one year.” [22] A serious perspective for the KRG reaction was to get prepared for the financial crisis and to have a strategic mechanism for determining what the KRG was getting from the Federal Government, and also, what was to do if the Federal Government would not pay. Then the KRG government would be able to export oil to provide its population with the needs, which in practise meant getting ready to practising the economic efficiency for the region. Accordingly, the Iraqi government has tried to revise and amend the constitution according to oil and revenue sharing, the first attempt was made during 2010-2011 and was twice failed, since the Prime Minister, Nuri Al-Maliki and his followers had tried to restrict the regional authority of the KRG and as the main purpose was to enact the new law for oil and gas, "in spite of having the Ministry of Oil, the Federal government also intended to create new entities in oil field such as the Iraqi National 
Oil Company (INOC) and, the Federal Oil and Gas Council (FOGC) besides the Bureau of Independent Advisors (BIA)." [23] A controversial issue is the incentives created by the Federal Government in increasing its monopoly through FOGC to review and control oil contracts both in the central government and in the KRG. In the new constitution, the FOGC got high authority in oil control as well "Article 18 of Iraq Oil Law of 17 August 2011, gives the right to BIA to review all new petroleum contracts.” [24]

The intention is clear that the Federal Government excludes the old petroleum contracts, since most newly signed contracts are in the Kurdistan Region, though another concern is that the BIA members ought to be foreign experts in which the Federal Government does not want foreign influence over oil. Ultimately, the Iraqi government wants to secure the guarantee of oil production under its authority. The core problem is the vagueness of the constitution, in addition to another very sensitive issue, the geographical location of the oil reserves in Iraq, in which "Iraq's oil reserves are mainly concentrated in Shiite areas of the south and Kurdish region in the north. Some reserves are also located in central Iraq.” [25] Therefore, the Sunni Arabs would never accept the de-Baathification of oil reserves and oil policy, because the zeal for autonomy of the Basra province had been a concern for the Shia population of the province too, as mentioned by Mohammed al-Taie, an MP representing Basra, who told Al-Akhbar: "Establishing a semi-autonomous region is necessary to organize the wealth and power in any country whose federal government has failed in its performance and management of the state.” [26] As a consequence, the decentralization is highly accepted by the Kurds and Shia Leaders, whereas, it has been rejected by Sunnis; at this point KRG is the only efficient region for having untapped petroleum reserves.

\section{Production Capacity of the Kurdistan Region in the Iraqi Oil Market}

To be noted, the Kurdistan Region was devastated by the thirteen years of Baath Regime's policy, thus the Kurdistan Region has worked hard to develop the energy sector, and the KRG's capacity of oil production is progressing consistently. As mentioned by Prime Minister Barham Salih (2011) "the days when Kurdistan was an economic backwater are over”. [27] Kurdistan Oil production is featured as the so-called easy oil, which does not require deep drilling. Being poorly reported, the data on the Iraq oil reserves are different but, "the Department of Energy (DOE) Energy Information Administration (EIA) figures claiming that the territory of Iraq contains over 112 billion barrels of proven reserves-oil that has been definitively discovered and is expected to be economically producible. Since, Iraq is the least explored of the oil-rich countries.” [28] Therefore, there is a possibility that most of all those unexplored fields are in the Kurdistan Region since the Iraqi Baath regime neglected the revenues in the Region. "Almost $43 \mathrm{~B} / \mathrm{b}$ are in Kurdistan region out of the $115 / \mathrm{Bb}$ of the Iraqi Crude Oil.” [29]

Additionally, the European Centre for Energy and Resource Security (EUCERS) stated that "natural gas reserves of Kurdistan are estimated at 100-200 trillion cubic feet-alternatively, 2.8-5.6 billion cubic meters-which is more than countries like Norway or Kazakhstan.” [30] Despite the fact that the Federal Government claims that it has an incentive in motivating investment in Iraqi, as mentioned in Article 26: "The state 
guarantees the encouragement of investments in the various sectors; this will be organized by law.” [7: Art. 26] But this is not the real picture for Kurdistan since the Federal Government restrains regional capacity in developing the energy sector. The disputes over oil production had affected the efficient regional and federal income usages in the country. The Federal Government's objection was yet not influential enough to stop all international investors to the Kurdistan Region, as the motto of the KRG was different from the central government. The production-sharing contracts (PSCs) have helped the KRG to attract many international oil companies to the Kurdistan Region since the early 2009. Acknowledged by Denise Natali, "the central government may also fear that paying the IOCs in the Kurdish north a greater profit margin than companies working in the south.” [31] The international perception in case of the KRG has been positive since; the Iraqi government avoids foreign control over oil while the KRG has better relations with the foreign companies. If energy security is a real concern for the international energy markets, then supporting the KRG to produce oil is needed. The two most significant concerns in Iraqi oil production are always taken into account seriously: the first is that the largest oil fields are in Southern Iraq and in Northern Iraq, in the Kurdistan Region, typically in "Kirkuk" over which the KRG and the Federal Government still have a territorial dispute.

Yet a deeper look into the situation and politics reveals a more complex scenario with uncertain outcomes. The political arena is volatile, with the emergence of different perspectives on losing sovereignty, the rejection of privatization of oil according to many Iraqi specialists results in the long term future economic drawbacks based on the interpretation of the fact that the company will have the right in sharing of the revenues for a long period, i.e. at least for 30 years. However, comparing the Kurdistan Region as an oil rich "virgin region" to other countries is not fair, since the discovery of oil in the Kurdistan Region is quite novel; so its case is different. Overall, the Federal Government wants to have the benefit and share return of oil exports to the central government to control the cash flow in the country. In explaining the importance of the Kurdistan Region in terms of geological location, which is part of the Zagros Fold Belt that is a prolific oil province in Iran and Iraq to the south and west. (Figure 1) 


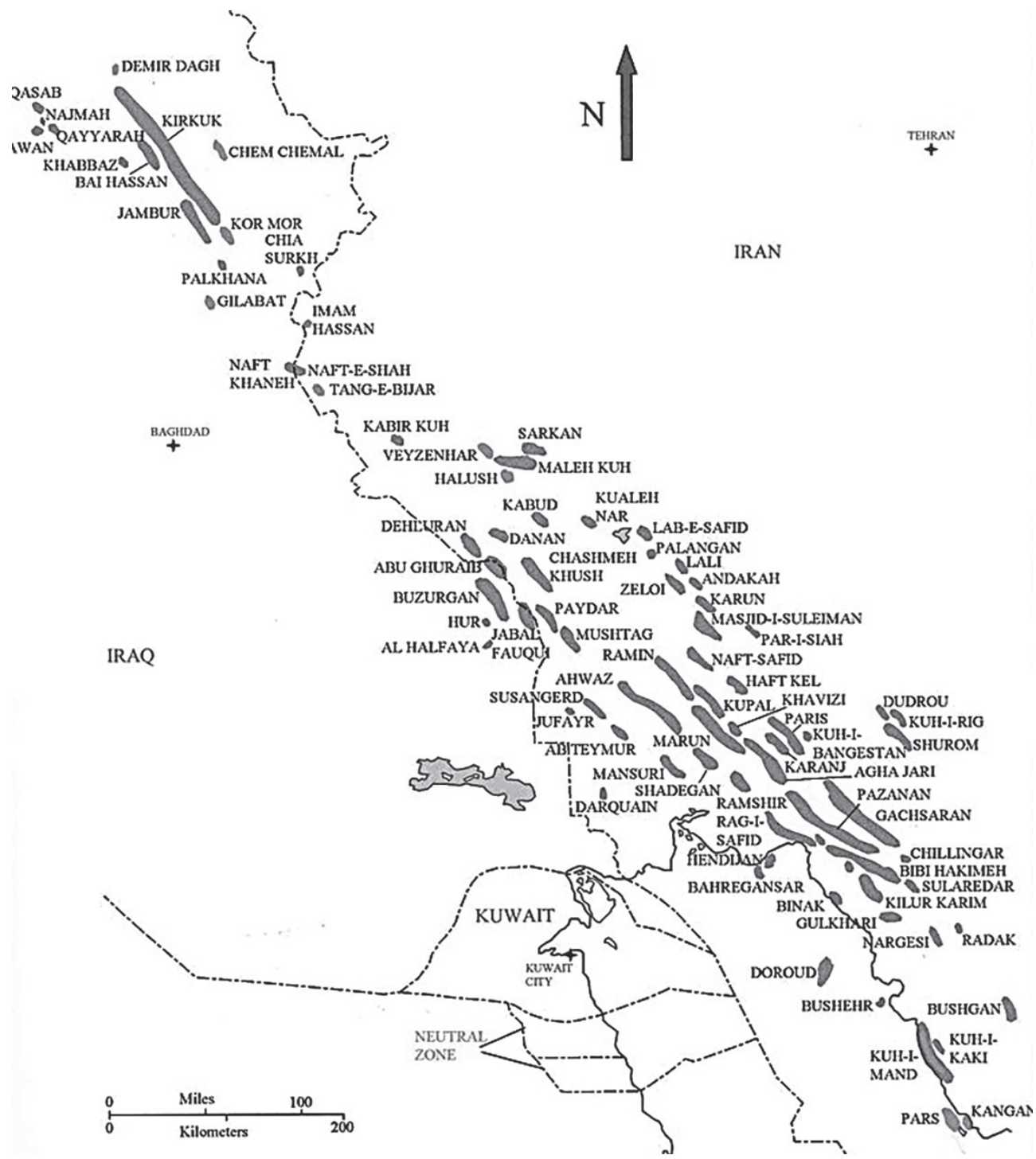

Figure 1. Iran oil fields. [47]

\section{The Lack of International Legacy in the KRG Status as an Autonomous Rich Energy Region}

The Kurdistan Region as an autonomous region is a geographically landlocked region; the region started the extraction of oil recently and typically after the 2007 disagreement with the Federal Government. In fact, the geographical role of the Kurdistan Region is critical, and the role of the Federal Government is stronger according to the constitution as well as according to the international status, Iraq is a sovereign state, while the KRG 
is a federal region in Iraq. Hence, Kurdistan has no sovereign power in any decision making according to international regulations, thus the Kurdistan Region does not have a say in the international energy markets yet, as a sovereign state or region. Certainly, the KRG practice of a more business-friendly approach is driven from the "good neighbour policy”. [16] The KRG's foreign energy policy is mainly dependent on Turkey as a neighbour country for the region at the present time. Although Iraq had a historical long-term relation with Turkey, recently, the Ankara-Baghdad relations had changed due to the KRG-Ankara ties. To put these results in context, according to the national interest both the KRG and Turkey have their own objectives to obtain. To begin with, the KRG-Federal Government relations are not certain and the issue of oil control is the main problem for both sides. A better explanation lies in the fact of federal sovereignty, whereas for the KRG, territorial claims and revenue control rights are important. The KRG energy ties with foreign countries are forbidden according to the Iraqi Federal Government and are illegal, besides the Federal Government has warned the foreign oil companies and countries for being involved in the KRG oil production and export. Interestingly, Ankara managed to work with both the Federal Government on the one hand, and the KRG, on the other hand. "We cannot ignore the energy resource next door to us", [32] as a result of the Turkish motive towards the KRG, the Iraqi-Turkish foreign relations were tensed, while Turkey started looking for better economic relations with the KRG. There is a significant potential in the Turkey-KRG energy partnership, since recently, Turkey's attitude had changed towards the Kurdistan Region, and the strategic relations are based on the economic contribution for both sides.

The interest lies in two dimensions, most importantly, in Turkey’s energy security, where the "domestic energy consumption rises by 6-8 percent annually." [33] Meanwhile, for energy, Turkey depends on Iran and Russia mainly, thus the emergence of the KRG is an alternative for decreasing the Russian and Iranian influence on Turkey's energy security. "It is being concluded that energy imported to Turkey in 2013 reached $\$ 55.9$ billion, almost about 22.2 percent of the total imports and about 56 percent of the total trade deficit of the country.” [34] In this analysis, the KRG is a stable energy supplier for the Turkish energy security. In the meantime, the Kurdistan Region needs a partner for supporting the exporting of its oil to the international energy markets. The KRG realized this weakness at the very beginning of the oil development; therefore, the energy policy with Turkey was a major concern for the KRG to take it into account seriously. The reality of the KRG energy foreign policy and economic development as a dependent region fits the model study which was conducted by Pal Kolsto and Helge Balkkisrud, whom revealed that "the unrecognized de facto states have tended to stress in their interaction with the international community their economic viability and prospects for economic survival.” [35] Although, having enough resources for the KRG means being sovereign, though the challenge is how to control them for domestic economic sovereignty and progress.

It bears emphasizing that the emergence of Kurdistan as an efficient de facto oil exporter relays on having free pipeline export to the international markets, which now the Kurdistan Region does not have, thus the diplomatic relations of the Kurdistan Region is fragile. Considering, the blooming economic cooperation with Turkey strengthens the role of the KRG in the region regardless of being a federal region. Within this context, the economic relations are remarkable for Turkey to diversify the domestic energy consumption, import via the KRG, as “Turkey’s domestic resources are not sufficient to meet the energy demand.” [36: 61] 
Besides, the KRG's economy is also depending on the Turkish products mainly, including the entire market needs, acknowledged by the Kurdish officials, "Turkey is the KRG's main business partner-trade volume is $\$ 7.7$ billion, 5 and 80 percent of Kurdish consumer imports come from Turkey.” [37] In this equation, the KRG's energy reserves are important for feeding the European energy market, particularly the present initiative of the KRG for gas export to Europe. Tony Hayward, Chairman of Genel Energy, said that "gas export will be far more strategic than oil export for the KRG, my expectation is that by the early 2020s, more than 20 billion cubic metres of gas a year will flow from the Kurdistan Region of Iraq into the Turkish market and into Europe.” [38] Apparently, international oil companies (IOCs) stayed in KRG even during the ISIS war, which gives credibility to the Kurdistan Region as an important offshore energy hub. Regarding recent updates in November 2015, "KRG's crude oil was sold for the first time the crude markets in North-Western Europe, this was the first oil barrels of KRG in the Baltic ports.” [39] Remarkably, exporting oil independently to almost 10 countries complicate the tension with the central government further. However, the Minister of Natural Resources of the KRG reckoned that "it is premature to disclose the names of traders, shippers and buyers of Kurdish oil.” [40] In fact, many countries are involved, yet it is elusive, as Stuart et al. mentioned, "with the federal government in Baghdad threatening to sue any buyer of Kurdish crude.” [41] In line with this, in a commentary in the European Council on Foreign Relations, [42] the role of the Kurdistan Region is mentioned among the reliable sources of secure energy for the European Union, "Iraq-and in particular, Kurdistan-is another potential supply option for Europe: it has massive oil and gas resources and international exploration and production companies are present and active”. Kurdistan, as mentioned, can be a sustainable energy supplier for the European Continent in the future, therefore, the dispute between the KRG and the Iraqi government is to be settled.

\section{Concluding Remarks}

To conclude, the role of oil revenues in the strengthening economic independence for the Kurdistan Region is extremely important. Moreover, the Kurdistan Region cannot be economically efficient, unless it finalizes the disputes with the Federal Government of Iraq, especially the constitutional disagreements on oil share and the territorial disputes, as well. A key ending of this analysis is the conclusion that the Kurdistan Regional Government seems to have yet a deeper concern about the regional petroleum revenues, since the regional politics reveals a more complex scenario with uncertain outcomes due to the federal-regional disputes on the one hand and the instability of Iraq on the other hand. The political arena is volatile, with the emergence of new threats that may affect the oil production. In spite of that, the success of the Kurdistan Region as a key oil producer depends on Turkey and the international oil companies. Eventually, the KRG can perform well by following different policies, especially such as the Production Sharing Agreements with International Oil Companies and good neighbour policy with Turkey. Causally, the KRG needs to focus on diversifying the chance for oil and gas transport via different channels and other countries to decrease the exclusive Turkish influence on the energy production of the Kurdistan Region. 
P. R. AHMAD: The Politics of Oil in the Kurdistan Region of Iraq

\section{References}

[1] SARDAR, A.: International oil companies and public right. December 2, 2013. www.payik.net/ all-details.aspx?jimare=258 (Downloaded: 22.11.2015), (Translated from Kurdish language.)

[2] BARZANI, N., (PM): Kurdistan Oil and Gas Law approved by Kurdistan Parliament. krg.org, August 6, 2007. http://cabinet.gov.krd/a/d.aspx?s=010000\&l=12\&a=19507 (Downloaded: 11.11.2015)

[3] GUY, C.: Iraq’s appeal wanes for oil majors. Financial Times, March 17, 2013. http://pictorial-guide-to-energy.blogspot.hu/2013_03_01_archive.html (Downloaded: 13.11.2015)

[4] The Investment Law. (Official English translation of the investment law.) http://belkib.com/ in-english.html. (Downloaded: 13.11.2015)

[5] Interview with Luis Martinez. In. French Oil Expert: Kurdistan Oil Deals Are Transparent and Standard Contracts. London, Erbil, Baghdaf: Iraq Energy Institute, November 12, 2012.

[6] Interview with, KRG, Agriculture Minister, Abdul-Star Majid. 2014. http:// hawlati.co/\%D8\%A6\%DB\%95\%D8\%B1\%D8\%B4\%DB\%8C\%DA\%A4\%DB\%95\%DA\%A9\%D8\%A7\%D9\%86/49649 (Downloaded: 22.11.2015)

[7] Iraqi Constitution, 2005. (English version.) www.washingtonpost.com/wp-dyn/content/ article/2005/10/12/AR2005101201450.html (Downloaded: 21.11.2015)

[8] KARL, T. L.: The Paradox of plenty: oil booms and petro-states. Oakland: University of California Press, 1997.

[9] State Oil Marketing Organisation, (SOMO). http://somooil.gov.iq/en/ (Downloaded: 04.11.2015)

[10] LEUBA, K.: Exxon's role in Iraq-Kurdistan relations. Cairo: The American University in Cairo, 2014. http://schools.aucegypt.edu/huss/pols/Khamasin/Pages/article.aspx?eid=15 (Downloaded: 25.11.2015)

[11] BADER-BLAU, S.: Iraqi unions vs. big oil. In. Middle East Research and Information project. MER 275, Vol. 45 (2015). www.merip.org/author/shawna-bader-blau (Downloaded: 25.11.2015)

[12] MUTTITT, G.: Fuel on the Fire: Oil and Politics in Occupied Iraq. Energy Policy, 39 (2011), 7482-7483.

[13] ABO: Blessed with resources. Interview with Ashti Hawrami, Kurdistan's Minister for Natural Resources. June, 2013. www.abo.net/oilportal/interview/view.do?contentId=2122237 (Downloaded: 22.11.2015)

[14] CAMERON, P. D.: Managing the Politics of Oil Reforms: Lessons from Iraq. Washington D.C.: Center for Energy, Petroleum \& Mineral Law and Policy, 2010.

[15] SHIVAN, F.: What Brings Oil Giants to Kurdistan? Kurdish Globe, July 22, 2013. www. kurdishglobe.net/article/851D1BB96C51323F04FBC7CBBC14A20E/What-Brings-Oil-Giantsto-Kurdistan-.html (Downloaded: 13.11.2015)

[16] IIG: Overview: Kurdistan Region of Iraq. Diplomacy \& Politics, July 30, 2013. www.investingroup.org/publications/kurdistan/overview/diplomacy-politics (Downloaded: 22.11.2015)

[17] Iraq threatens legal action against any buyer of Kurdistan oil. EKurd Daily (online), June 1, 2015. http://ekurd.net/mismas/articles/misc2014/6/state8043.htm (Downloaded: 23.11.2015)

[18] Total investing in Kurdistan oil despite threats. Market Watch (online), August 21, 2012. accessed on November 21, 2015, available online at: www.marketwatch.com/story/total-investing-in-kurdistan-oil-despite-threats-2012-08-21 (Downloaded: 23.11.2015) 
[19] PEG, M.: Sell again weighs energy openings in Iraqi Kurdistan. Reuters (online), September 21, 2012. http://uk.reuters.com/article/2012/09/21/uk-shell-iraq-kurdistan-idUKBRE88K0YC20120921 (Downloaded: 21.11.2015)

[20] OGIB RESEARCH TEAM: Iraq - Kurdistan’s Billion-Barrel Oil Investment. Oil and Gas Investment Bulletin (online), March 27, 2013. http://oilandgas-investments.com/2013/investing/ iraq-kurdistan-oil-investment (Downloaded: 21.11.2015)

[21] KORNEY, S., GOLDEN, G. J., AMIRI, A.: Moving towards direct oil exports from the Kurdistan region of Iraq. Lexology (online), June 11, 2013. www.lexology.com/library/detail. aspx?g=fa8e7f9c-6f37-4ad8-b052-a72a542e9cbc (Downloaded: 10.11.2015)

[22] KAYAKIRAN, F.: Iraqi Kurds to pay oil exporters \$75 million with more to follow. Bloomberg (online), November 7, 2014. www.bloomberg.com/news/2014-11-07/iraqi-kurds-to-pay-oilexporters-75-million-with-more-to-follow.html (Downloaded: 21.11.2015)

[23] KORNEY, S., SATTAROVA, S., AL-MALIK, M.: Two are not always better than one: Iraq is competing oil and gas laws. Lexology (online), October 14, 2011. www.lexology.com/library/ detail.aspx?g=546ce703-21a9-4163-b5cc-b7c8e67c3101 (Downloaded: 10.11.2015)

[24] AHMED, A. M.: Preliminary remarks on the new version of oil law. Norway: Iraq/Development Consultancy and Research, 2011. www.iraq-businessnews.com/wp-content/uploads/2011/08/ Ahmed-Mousa-Jiyad-Preliminary-Remarks-on-the-Parliament-New-Version-of-the-Oil-Law2. doc (Downloaded: 10.11.2015)

[25] GUPTA, A.: Countries with the biggest oil reserves. October 30, 2013. www.hydrocarbons-technology.com/features/feature-countries-with-the-biggest-oil-reserves (Downloaded: 20.11.2015)

[26] AL-MASHHADANI, M.: Can Iraq's Basra province become the Kurdistan of the south? Al-Akhbar English (online), December 4, 2014. http://english.al-akhbar.com/node/22755 (Downloaded: 23.11.2015)

[27] UPI: As Iraq smoulders, Kurds sit on oil riches. December 22, 2011. www.upi.com/Business_ News/Energy-Industry/2011/12/22/As-Iraq-smolders-Kurds-sit-on-oil-riches/97641324580189 (Downloaded: 20.11.2015)

[28] LUFT, G.: How Much Oil Does Iraq Have? Washington D.C.: Brookings Institution, 2003. www.brookings.edu/research/papers/2003/05/12globalenvironment-luft (Downloaded: 25.11.2015)

[29] BARZNJI, N.: Oil in Kurdistan region. April 3, 2014. http://bzavpress.com/Detail.aspx?id=2962\&LinkID=2 (Downloaded: 23.11.2015)

[30] PFLÜGER, F., DUERO, A.: New stability and prospects for Kurdish oil and gas. Elektor (online), December 5, 2011. www.elektormagazine.com/news/New-Stability-and-Prospects-forKurdish-Oil-and-Gas (Downloaded: 23.11.2015)

[31] NATALI, D.: The politics of Kurdish crude. Middle East Policy Council, Journal Essay, XIX 1 (2012). www.mepc.org/journal/middle-east-policy-archives/politics-kurdish-crude?print (Downloaded: 27.11.2015)

[32] CETINGULEC, M.: Turkey pivots to Baghdad to close deal on Kurdish oil. Al-Monitor (online), May 19, 2013. www.al-monitor.com/pulse/originals/2014/05/turkey-needs-baghdadpermission-sell-kurdish-oil.html\# (Downloaded: 23.11.2015)

[33] TOCCI, N.: Turkey’s Kurdish Gamble. IAI Working Papers (online), 1310 (2013). www.iai.it/ sites/default/files/iaiwp1310.pdf (Downloaded: 20.11.2015) 
[34] YEREVAN, S.: Kurdistan's energy resources could be a defining point of Turkey's foreign policy. Diplomatic Courier: A Global Affairs Magazine (online), July 24, 2014. www.diplomaticourier.com/2014/07/24/kurdistan-s-energy-resources-could-be-defining-point-of-turkey-s-foreign-policy/ (Downloaded: 24.11.2015)

[35] VOLLER, Y.: From rebellion to de facto statehood: international and transnational sources of the transformation of the Kurdish national liberation movement in Iraq into the Kurdistan regional government. (Ph.D. dissertation) London: University of London, London School of Economics and Political Science, 2012.

[36] ERENSU, S.: Abundance and scarcity amidst the crisis of 'modern water'. In. HARRIS, L. M., GOLDIN, J. A., SNEDDON, C. (eds.): Contemporary Water Governance in the Global South. Scarcity, Marketization and Participation. London and New York: Routledge, 2013. Part II/6.

[37] SONER, C., TYLER, E. (2012). Turkey’s changing relations with Iraq: Kurdistan up, Baghdad down. Washington D.C.: Washington Institute for Near East Policy, 2012.

[38] Minister of Natural Resources Speech. Ashti Hawtami on the website of the Ministry of Natural Resources of KRG. http://mnr.krg.org/index.php/en/press-releases/513-minister-hawrami-sayskurdistan-makes-progress-on-gas-export-to-turkey-and-europe-krg-s-direct-oil-sales-fund-waragainst-isis (Downloaded: 23.11.2015)

[39] GORODYANKIN, G.: Kurdish oil reaches Baltic, targets Russian markets. Reuters (online), November 8, 2015. www.reuters.com/article/2015/11/18/us-kurdistan-oil-europe-idUSKCN0T72LP20151118\#m829xQucS49PMs8o.97 (Downloaded: 27.11.2015)

[40] ZHDANNIKOV, D.: Exclusive: How Kurdistan bypassed Baghdad and sold oil on global markets. Reuters (online), November 17, 2015. www.reuters.com/article/2015/11/17/us-iraq-kurdistan-oil-idUSKCN0T61HH20151117\#3qr5VG1QCr4tbZ34.97 (Downloaded: 26.11.2015)

[41] STUART, E., LANINGHAM, P. van, MORLEY, J.: Iraqi Kurdish crude oil exports win favour in Europe. Middle East Energy Focus (online), August 27, 2015. www.platts.com/ news-feature/2015/oil/middle-east-energy-focus/kurdish-crude-exports-082815 (Downloaded: 26.11.2015)

[42] CHYONG, C., SLAVKOVA, L., TCHERNEVA, V.: Europe’s alternative to Russian gas. London: European Council on Foreign Relations, 2015. www.ecfr.eu/article/commentary_europes_ alternatives_to_russian_gas311666 (Downloaded: 22.11.2015)

[43] MUSTAFA, N.: Oil Dispute between KRG and Federal government. Sbeiy.com, November 28, 2007. www.sbeiy.com/(X(1)S(3m4f40sf4m4h12jtb3pd40ed))/ku/article_detail.aspx?ArticleID=278\&AuthorID=36 (Downloaded: 20.11.2015)

[44] RUDAW: Erbil says no breakthrough in energy, budget talks with Iraqi team. April 15, 2014. http://rudaw.net/english/kurdistan/15042014 (Downloaded: 21.11.2015)

[45] Oil and Gas Law of the Kurdistan Region - Iraq, 2007. http://cabinet.gov.krd/uploads/documents/Kurdistan\%20Oil\%20and\%20Gas\%20Law\%20English_2007_09_06_h14m0s42.pdf (Downloaded: 20.11.2015)

[46] Kurdistan Development Corporation, Industry Sectors: Agriculture. Erbil, Kurdistan Region: Ministry of Agriculture and Water Resources, Directorate General of Planning and Follow-Up, Directorate of Statistics, 2007.

[47] Iran: 14 new oil and gas fields to be put up for tender. energy-pedia.news, s.d. www.energy-pedia. com/news/iran/14-new-oil-and-gas-fields-to-be-put-up-for-tender (Downloaded: 20.11.2018) 